\title{
MIKROENKAPSULASI EKSTRAK AMPAS JAHE MERAH DARI HASIL PEMISAHAN MINYAK JAHE MERAH
}

\author{
[Microencapsulation of Dregs Red Ginger Extract From Red Ginger Oil] \\ Novaldi $^{{ }^{\star}}$, Prismawiryanti ${ }^{1}$, Jaya Hardi ${ }^{1}$, Hardi $Y s^{1}$ \\ 1) Jurusan Kimia, Fakultas MIPA, Universitas Tadulako, Palu \\ Jl. Soekarno Hatta Km.9, Kampus Bumi Tadulako Tondo Palu, Telp. 0451- 422611 \\ *)Coresponding author: novaldiciko@ymail.com (082345770356)
}

Diterima 17 November 2018, Disetujui 18 Januari 2019

\begin{abstract}
The dregs red ginger extract from red ginger oil distillation contains oleoresin compounds that are easily damaged. Therefore, microencapsulation is necessary to maintenance the stability of the dregs red ginger extract using maltodextrin. The extraction was carried out using $96 \%$ of ethanol solvent with five ratio, were 1:6, 1: 7, 1:8,1:9 and 1:10 (w/v), respectively. Microencapsulation was carried out with coating method and freeze drying technique. The ratio of maltodextrin and dregs red ginger extract were $1: 6,1: 7,1: 8,1: 9$ and $1: 10(\mathrm{w} / \mathrm{w})$, respectively. The results showed that the highest yield of dregs red ginger extract was $1: 10(\mathrm{w} / \mathrm{v})$ with $31,82 \%$. The highest efficiency ratio of coating extract of dregs red ginger with maltodextrin was 1: 6 with percentage of $55,04 \%$.
\end{abstract}

Keywords : Dregs red ginger extract, freeze drying, coating, maltodextrin

\begin{abstract}
ABSTRAK
Ekstrak ampas jahe merah hasil penyulingan minyak jahe merah mengandung senyawa oleoresin yang mudah rusak. Untuk menahan kerusakannya dilakukan mikroenkapsulasi menggunakan maltodekstrin. Ekstraksi dilakukan menggunakan pelarut etanol $96 \%$ dengan lima rasio perbandingan, yaitu 1:6, 1:7, 1:8, 1:9 dan 1:10 (b/v). Mikroenkapsulasi dilakukan metode penyalutan dan teknik freeze drying. Perbandingan maltodekstrin dan ekstrak ampas jahe merah yaitu 1:6, 1:7, 1:8, 1:9 dan 1:10 (b/b). Hasil penelitian menunjukkan bahwa rendemen ekstrak ampas jahe merah yang diperoleh tertinggi pada rasio 1:10 dengan kadar $31,82 \%$. Efisiensi penyalutan ekstrak ampas jahe merah dengan maltodekstrin yang diperoleh tertinggi pada rasio 1:6 yaitu 55,04\%.
\end{abstract}

Kata kunci: Ekstrak ampas jahe merah, freeze drying, penyalutan, maltodekstrin 


\section{LATAR BELAKANG}

Jahe merah (Zinggiber officinale var. rubrum) termasuk salah satu sumber minyak atsiri dan oleoresin potensial. Produksi jahe di Indonesia pada tahun 2010 mencapai 17,1 ton per hektar (BPS, 2011). Produksi jahe meningkat pada tahun 2013 mencapai 155,29 ton dan tahun 2014 mencapai 226,097 ton (BPS, 2014). Peningkatan produksi tiap tahunnya dapat diindikasikan bahwa nilai ekonomi dari minyak atsiri jahe memiliki nilai ekonomi yang tinggi bahkan lebih tinggi dibandingkan dengan minyak nilam dan minyak atsiri lainnya kecuali minyak pala (Nurlaili et al., 2014).

Kadungan minyak atsiri jahe merah hasil penyulingan dapat mencapai 2,58 $3,72 \%$ atau lebih banyak dibanding kandungan minyak atsiri dari jenis jahe lainnya, diantaranya jahe gajah 1,622,29\% dan jahe emprit sebesar 3,053,48\% (Herlina et al., 2002; Daryono, 2010). Pada saat penyulingan minyak atsiri dari jahe terdapat hasil samping berupa ampas dalam jumlah yang cukup banyak. Pada usaha penyulingan, ampas digunakan sebagai bahan bakar pada satu sisi dan pada sisi lain ampas masih mengandung senyawa kimia yang berguna yakni senyawa tidak mudah menguap (non volatile) dalam jahe. Senyawa non volatile dalam jahe disebut oleoresin dengan kandungan senyawa berupa gingerol, zingiberol, shagaol dan zingiberen (Wresdiyati et al., 2003).
Rendemen oleoresin jahe merah sekitar $3 \%$ (Herlina et al., 2002). Gingerol termasuk senyawa yang memberikan rasa pedas pada jahe dan termasuk salah satu komponen senyawa pada jahe yang berperanan sebagai antidiare, antimikroba, antioksidan, antihepatotoksik dan antipiretik (Wresdiyati et al., 2003; Norajit et al., 2007; Dawani et al., 2010).

Pemanfaatan ampas jahe yang dihasilkan dari proses penyulingan minyak jahe telah dilakukan oleh Budi (2009) dan Nurlaili et al. (2014). Penelitian Budi (2009) menggunakan nHeksan sebagai pelarut pengektrak ampas jahe kering menghasilkan rendemen oleoresin dengan rasio 1: 4,67 sebesar $1,27 \%$ dan Nurlaili et al. (2014) menggunakan etanol $95 \%$ sebagai pelarut pengekstrak pada berbagai rasio pelarut terhadap ampas jahe kering dengan rendemen oleoresin tertinggi terdapat pada rasio $1: 6$ (1 bagian ampas jahe merah, 6 bagian pelarut) sebesar 6,97\% (Nurlaili et al., 2014). Rendemen tersebut masih mungkin meningkat seiring meningkatnya volume pelarut sebab rasio tertinggi yang diterapkan oleh Nurlaili et al. (2014) adalah $1: 6$ dari dua rasio lainnya (1:4 dan 1:5). Amir dan Lestari (2013) dalam penelitiannya menjelaskan jenis pelarut yang digunakan dalam proses ekstraksi akan mempengaruhi kelarutan komponen dalam bahan. Pelarut semi polar seperti 
etanol dan aseton memberikan konsentrasi oleoresin lebih besar daripada pelarut non polar. Sehingga, penggunaan pelarut etanol sebagai pengekstrak ampas jahe sangat cocok dalam menghasilkan rendemen oleoresin yang tertinggi.

Komponen senyawa dalam oleoresin jahe sangat peka teradap suhu, cahaya dan logam-logam tertentu (Nurlaili et al., 2014). Komponen utama oleoresin yakni gingerol. Senyawa gingerol sangat peka terhadap suhu diatas $45^{\circ} \mathrm{C}$ dikarenakan akan mengalami kerusakan dekomposisi sehingga akan berubah menjadi shogaol yang kualitasnya lebih rendah dibanding gingerol. Untuk mencegah kerusakan yang disebabkan karena adanya paparan cahaya, perlu dilakukan perindungan oleoresin melalui proses penyalutan atau mikroenkapsulasi. Efisiensi penyalutan sangat ditentukan oleh bahan penyalut yang digunakan dan metode penyalutan atau mikroenkapsulasi. Kajian penggunaan maltodekstrin sebagai penyalut oleoresin telah dilakukan dengan perlakuan rasio ekstrak oleoresin terhadap maltodekstrin dan diketahui bahwa rasio terbaik untuk efisiensi penyalutan adalah pada rasio 1:16,7 (1 bagian ekstrak oleoresin dan 16,7 maltodekstrin) dari dua rasio lainnya (1:25 dan 1:50) menggunakan metode pengeringan semprot Nurlaili et al. (2014). Efisiensi penyalutan dari hasil penelitian tersebut masih mungkin meningkat dengan penurunan penggunaan maltodekstrin, sebab rasio $1: 16,7$ yang merupakan rasio tertinggi hanya menghasilkan efisiensi $22,13 \%$.

Oleh karena itu, dalam penelitian ini akan dikaji jumlah pelarut etanol yang menghasilkan rendemen ekstrak ampas jahe merah tertinggi dan massa maltodekstrin terhadap ekstrak yang menghasilkan efisiensi penyalutan tertinggi.

\section{METODE PENELITIAN}

\section{Bahan dan Peralatan}

Bahan yang digunakan pada penelitian ini yakni ampas jahe merah (Zingiber officinale var. rubrum), aquadest, etanol 96\%, maltodekstrin, kemasan plastik dan kertas saring Whattman.

Peralatan yang digunakan pada penelitian ini yakni aluminium foil, blender, ayakan 60 mesh, neraca analitik, mesin agitasi, desikator, rotary vacum evaporator, oven, moisture balance, pengering beku (freeze dryer) dan alatalat gelas yang umum digunakan dalam Laboratorium Kimia.

\section{Prosedur Penelitian}

\section{Ekstraksi Oleoresin}

Ekstraksi oleoresin ampas jahe merah dilakukan menggunakan metode maserasi (Nurlaili et al., 2014). Ampas jahe merah bentuk tepung sebanyak 50 gram dimasukkan ke dalam erlenmeyer 1 L. Kemudian, ditambahkan pelarut etanol $96 \%$ dengan perbandingan sesuai 
perlakuan $(1: 6 ; 1: 7 ; 1: 8 ; 1: 9 ;$ dan $1: 10)$ (b/v) dan di aduk selama beberapa menit. Campuran didiamkan selama 24 jam kemudian disaring menggunakan kertas saring whattman. Ampas jahe merah diekstraksi kembali dengan cara yang sama seperti perlakuan sebelumnya hingga 3 kali dan filtrat yang diperoleh disatukan. Kemudian, diuapkan pelarutnya secara vakum menggunakan alat rotary vacuum evaporator. Penguapan pelarut disempurnakan dengan gas nitrogen. Ekstrak yang diperoleh ditimbang untuk mengetahui rendemennya.

\section{Mikroenkapsulasi Oleoresin Ampas Jahe Merah}

Mikroenkapsulasi ekstrak ampas jahe merah dilakukan menggunakan metode pengeringan beku (freeze drying). Ekstrak ampas jahe merah dicampur dengan maltodekstrin dengan perbandingan sesuai perlakuan (1:6; $1: 7 ; 1: 8 ; 1: 9$; dan 1:10) (b/b). Campuran ditambahkan aquadest dengan perbandingan 1:20 (1 bagian campuran ekstrak ampas jahe merah-maltodekstrin dan 20 bagian aquadest) (b/v). Kemudian, campuran diaduk selama 1 jam dengan mesin agitasi 600 rpm. Selanjutnya, campuran didinginkan dalam lemari pendingin hingga beku. Kemudian, dikeringkan dengan alat pengering beku. Mikrokapsul yang dihasilkan ditentukan efisiensinya melalui penentuan kadar total ekstrak ampas jahe merah mikrokapsul dan kadar ekstrak ampas jahe merah permukaan mikrokapsul.

\section{Analisis Efisiensi Penyalutan}

Penentuan efisiensi dihitung dari persentase rasio oleoresin yang terkapsulkan dengan oleoresin awal (Khaushik et al., 2007 ) .

Efisiensi Penyalutan (\%) =

$\frac{\text { Massa total minyak }(\mathrm{g}) \text {-Massa minyak dipermukaan }(\mathrm{g}) \times \frac{a}{b}}{\text { Massa awal ekstrak }(\mathrm{g})} \times 100$ Keterangan :

$\mathrm{a}=$ Massa Mikrokapsul total $(\mathrm{g})$

$\mathrm{b}=$ Massa Mikrokapsul yang digunakan pada penentuan Efisiensi (g)

\section{HASIL DAN PEMBAHASAN}

\section{Oleoresin Ampas Jahe Merah}

Hasil ekstraksi ampas jahe merah diperoleh seyawa yang tidak menguap yakni oleoresin. Rendemen ekstrak ampas jahe merah dihasilkan dari proses ekstraksi ampas jahe merah dengan pelarut etanol $96 \%$ menggunakan metode maserasi.

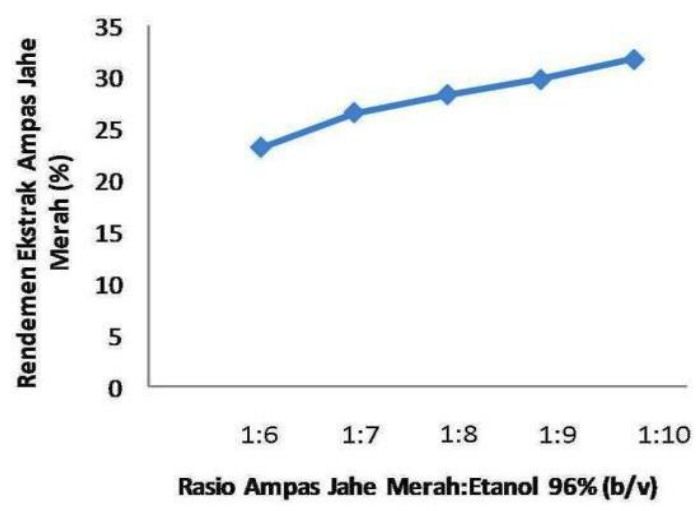

Gambar 1 Rendemen ekstrak ampas jahe merah pada berbagai rasio ekstrak terhadap etanol 
Gambar 1 menunjukkan bahwa rendemen ekstrak ampas jahe merah yang dihasilkan mengalami peningkatan seiring bertambahnya pelarut etanol. Hasil rendemen ekstrak ampas jahe merah yang dihasilkan tiap rasio 1:6, $1: 7,1: 8,1: 9$, dan 1:10 masing-masing sebesar 23,16\%; 26,58\%; 28,36\%; $29,84 \%$; dan $31,82 \%$. Rendemen yang diperoleh lebih tinggi daripada oleoresin jahe putih (rasio 1:6) dengan hanya memperoleh 16,06\% (Desmawarni, 2007). Menurut Azian et al. (2004) dalam Nurlaili et al. (2014), tingginya rendemen oleoresin yang disebabkan karena meningkatnya kerusakan dinding sel rimpang jahe yang melindungi oleoresin sehingga proses ekstraksi menjadi lebih efektif. Rendemen oleoresin semakin tinggi seiring dengan semakin banyaknya volume pelarut yang digunakan. Volume pelarut yang semakin tinggi akan menyebabkan daya larut oleoresin tinggi hingga mencapai titik optimum dimana pelarut telah jenuh (Suryandari, 1981).

\section{Efisiensi Penyalutan pada Berbagai Rasio Oleoresin Ampas Jahe Merah Terhadap Maltodekstrin}

Efisiensi mikrokapsul ekstrak ampas jahe merah-maltodekstrin merupakan efektifitas ekstrak ampas jahe merah pada mikrokapsul ekstrak ampas jahe merah-maltodekstrin baik dalam bahan inti maupun pada permukaan mikrokapsul. Semakin tinggi rasio konsentrasi mikrokapsul ekstrak ampas jahe merah-maltodekstrin maka semakin rendah nilai efisiensi penyalutan ekstrak ampas jahe merahmaltodekstrin yang dihasilkan (Gambar 2).

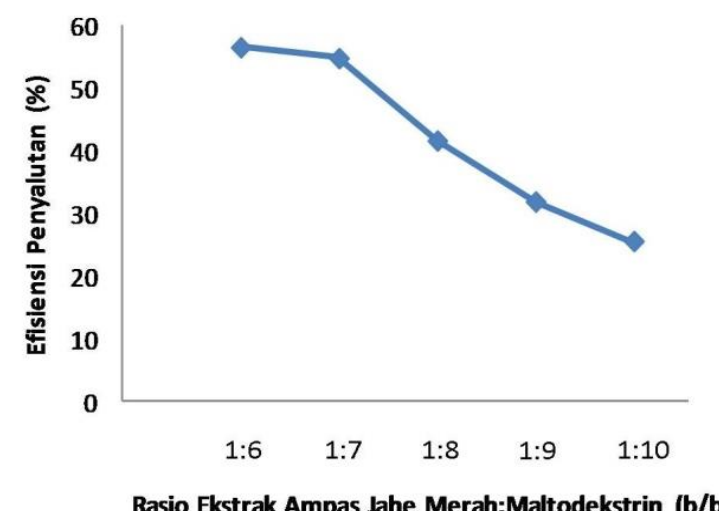

Gambar 2 Efisiensi penyalutan ekstrak ampas jahe merah pada berbagai rasio ekstrak terhadap maltodekstrin

Hasil efisiensi penyalutan ekstrak oleoresin ampas jahe merahmaltodekstrin yang dihasilkan tiap rasio $1: 6,1: 7,1: 8,1: 9$, dan $1: 10$ masingmasing sebesar 55,04\%; 54,61\%; 43,28\%; 31,56\%; dan 27,14\%.

Efisiensi penyalutan ekstrak ampas jahe merah-maltodekstrin tertinggi terdapat pada rasio $1: 6$ sebesar $55,04 \%$. Hasil yang diperolej lebih tinggi daripada mikrokapsul oleoresin jahe yang dilakukan oleh Nurlaili et al. (2014) yang hanya memperoleh 22,13\%. Menurunnya efisiensi enkapsulasi dapat dipengaruhi oleh meningkatnya konsentrasi enkapsulan yang digunakan dan viskositas emulsi yang tinggi. Menurut Rosenberg et al. (1985), viskositas emulsi yang tinggi akan 
menyebabkan turunnya nilai efisiensi enkapsulasi tau efisiensi penyalutan. Kondisi ini akan menyebabkan sulitnya proses atomisasi pada alat pengering sehingga banyak ekstrak ampas jahe merah yang keluar dan tidak terkapsulkan.

\section{KESIMPULAN}

Rendemen ekstrak ekstrak ampas jahe merah dari ampas jahe merah tertinggi diperoleh pada rasio 1:10 (b/v) sebesar $31,82 \%$. Efisiensi penyalutan ekstrak ampas jahe merah-maltodekstrin tertinggi diperoleh pada rasio 1:6 (b/b) sebesar $55,04 \%$.

\section{DAFTAR PUSTAKA}

Amir, A. N. dan Lestari, P. F. 2013. Pengambilan Oleoresin Dari Limbah Ampas Jahe Industri Jamu (PT. Sido Muncul) Dengan Metode Ekstraksi. Jurnal Teknologi Kimia dan Industri, 2(3)

Azian, M. N., Kamal, A. A. M. dan Azlina, M. N. 2004. Changes of Cell Structure in Ginger During Processing. Journal of Food Engineering, 62: 359-364.

BPS. (2011). Luas Panen, Produksi dan Produktivitas Jahe, Indonesia, 2010. http://www.bps.go.id. Diakses pada tanggal 25 Oktober 2018

BPS. 2014. Produksi Jahe Di Indonesia Tahun 2011-2014. https://bps.go.id. Diakses pada tanggal 25 Oktober 2018.

Budi, F. S. 2009. Pengambilan Oleoresin dari Ampas Jahe
(Hasil Samping Penyulingan Minyak Jahe) Dengan Proses Ekstraksi. Teknik, 30(3):156-162.

Desmawarni. 2007. Pengaruh Komposisi Bahan Penyalut Dan Kondisi Spray Drying Terhadap Karakteristik Mikrokapsul Oleoresin Jahe. Skripsi. Bogor: Institut Pertanian Bogor.

Daryono, E. D. 2010. Oleoresin dari Jahe Menggunakan Proses Ekstraksi Dengan Pelarut Etanol. Skripsi. Malang: Jurusan Teknik Kimia Fakultas Teknologi Industri. ITN.

Herlina, R., Murhananto, Endah, J., Listyarini, T. dan Pribadi, S. T. 2002. Khasiat Manfaat Jahe Merah Si Rimpang Ajaib. Jakarta: Agro Media Pustaka.

Khaushik, Vikas dan Roos,Y. H. 2007. Limonen Encapsulation In Freeze-Drying of Gum ArabicSucrose-Gelatin Systems. LWT Food Science and Technology 40: 1381-1391.

Nurlaili, F. A., Darmadji, P. dan Pranoto, $\quad$ Y. 2014. Mikroenkapsulasi Oleoresin Ampas Jahe (Zingiber Officinale Var.Rubrum) Dengan Penyalut Maltodekstrin. Jurnal AGRITECH, 34(1).

Norajit, K., Laohakunjit, N. dan Kerdchoechuen, O. 2007. Antibacterial Effect of Five Zingiberaceae Essential Oils. Molecules 12(8): 2047-2060.

Rosenberg, M., Kopelman, I. J. and Talmon, Y. (985. A Scanning Elektron Microscopy Study of Microencapsulation. Journal of Food Sience 50(1): 1138-44. 
Suryandari, S. 1981. Pengambilan Oleoresin Dengan Cara Solvent Extraction. Bogor: BPIHP.

Wresdiyati, T., Astawan. M., Adnyane I $\mathrm{K}$ M. 2003. Aktivitas Anti Inflamasi Oleoresin Jahe (Zingiber officinale) Pada Ginjal Tikus Yang Mengalami Perlakuan Stres. Jurnal.Teknol. dan Industri Pangan, 14(2): 113120. 